\title{
FIESTAS NACIONALES EN TIEMPOS IMPERIALES: COSTA RICA FRENTE A ESTADOS UNIDOS (1891-1921)
}

\author{
Victor H. Acuña Ortega \\ Universidad de Costa Rica \\ (San José, Costa Rica) \\ ORCID: https://orcid.org/0000-0002-4901-7407 \\ vhacuna@gmail.com
}

Este artículo describe las conmemoraciones realizadas en Costa Rica en el periodo 18911921 para celebrar su independencia política y su identidad nacional y las analiza como formas de recepción de la relación imperial impuesta por Estados Unidos a las sociedades y a los estados centroamericanos a inicios del siglo XX. Se describen también los cambios en las formas y los contenidos de estos festejos durante el periodo.

Palabras ClaVE: Centroamérica / Estados Unidos / Identidad nacional / Conmemoraciones / imperio.

\section{NATIONAL FESTIVITIES IN IMPERIAL TIMES: Costa RICA FACING UNITED STATES (1891- 1921)}

This article describes the Costa Rican civic national festivities between 1891 and 1921. The article discusses these celebrations as a response from the Costa Rican state and society to deal with the arrival of the United States as an imperial power in Central America at the beginning of the twentieth century. The article also addresses the changes in shape and content of the festivities.

KEYWORDS: Central America / United States / National identity / Commemoration / Empire. 
En setiembre de 1891 se inauguró en la ciudad de Alajuela, cercana a la capital, el monumento a Juan Santamaría, héroe popular costarricense de la guerra de los estados centroamericanos contra los filibusteros de William Walker (1856-1857). En setiembre de 1921, las repúblicas centroamericanas, con gran pompa, celebraron conjunta y simultáneamente el centenario de su independencia de España. En este arco de treinta años, Costa Rica y Centroamérica realizaron otras conmemoraciones con el fin de celebrar las respectivas naciones, la unidad centroamericana y el fundamento hispánico de su identidad. Todos estos festejos surgieron en el periodo en el cual Estados Unidos como imperio estableció un sistema de estados clientes en el Caribe y la América Central. ${ }^{1}$ En este trabajo voy a explorar los silencios, las alusiones y las declaraciones frente a esta realidad que pueden rastrearse en el marco de esas fiestas y también prestaré atención a los rituales y ceremoniales que en ellas fueron desplegados. Esta va a ser mi manera de rendir tributo y establecer un diálogo con una parte de la obra del colega y amigo Juan Carlos Garavaglia. $^{2}$

La hipótesis que se propone es que la fiesta cívica formó parte del conjunto de recursos utilizados por Costa Rica y los otros estados centroamericanos en su proceso de recepción de la relación imperial impuesta por Estados Unidos en el tránsito del siglo XIX al siglo xx. En efecto, una manera indirecta de enfrentar la llegada de esta condición de subordinación fue la promoción de las conmemoraciones. De este modo, en el periodo en cuestión, desde las esferas gubernamentales, al inicio, y desde la sociedad civil, posteriormente, con el apoyo de la prensa, surgieron iniciativas para festejar distintos eventos y personajes, la mayoría de ellos centrados en la guerra de 1856-1857.

Tales fiestas fueron las siguientes: la inauguración de la estatua de Juan Santamaría en la ciudad de Alajuela, en 1891; la celebración del cuarto centenario del «descubrimiento de América», en 1892; la inauguración del Monumento Nacional, conmemorativo de la citada guerra contra Walker, en 1895; los festejos del centenario del así llamado «grito de independencia de San Salvador», en 1911; el centenario del nacimiento del presidente Juan Rafael Mora, líder de la guerra antifilibustera, en 1914; la efemérides del 11 de Abril en honor de Juan Santamaría y en memoria de la batalla de Rivas, Nicaragua, de 1856, oficializada en 1915 y celebrada en 1916; la oficialización y la celebración del «día de la raza», el 12 de octubre, en 1915; finalmente, los festejos del centenario de la independencia de Centroamérica, en 1921. Se debe agregar que el 1. ' de mayo de 1913 fue celebrado por primera vez en Costa Rica el «día del trabajo».

1. Coatsworth, John H., Central America and the United States. The Clients and the Colossus, New York, Twayne Publishers, 1994; en particular el capítulo 1.

2. Me refiero a sus trabajos: «Del Corpus a los Toros: fiesta, ritual y sociedad en el Río de la Plata colonial», «A la nación por la fiesta: las Fiestas Mayas en el origen de la nación en el Plata y «Buenos Aires y Salta en rito cívico: la revolución y las Fiestas Mayas», incluidos en su libro Construir el estado, inventar la nación. El río de la Plata, siglos XVIII-XIX, Buenos Aires, Prometeo Libros, 2007. 


\section{La inauguración del monumento a Juan Santamaría en 1891}

El ciclo de conmemoraciones que se abre con este evento y que culmina con el centenario de la independencia de España, había sido precedido por la instauración de la efeméride del 15 de setiembre como fiesta de la independencia de Centroamérica, decretada por la República Federal, en 1824. En Costa Rica, el festejo empezó a celebrarse con cierta regularidad a partir de 1848, cuando este país se proclamó república para separarse formalmente de la fenecida Federación; alcanzó total continuidad desde 1875 y el ceremonial adquirió un carácter plenamente secular, libre de vestigios coloniales, en la década de 1880, con la llegada al poder de los liberales. Garavaglia señala también que en el Río de la Plata tales festejos mezclaron elementos de la época colonial, en especial el ritual religioso y los entretenimientos populares, con la nueva liturgia republicana durante algún tiempo después de la independencia, antes de su total secularización. Así, al inicio de la década de 1890, la celebración cívica del 15 de setiembre en conmemoración de la independencia de Centroamérica proclamada en la ciudad de Guatemala en 1821 estaba bien asentada en el calendario del recién formado Estado costarricense y de su joven nación en proceso de invención de sus señas de identidad. Pero, aparte de dicho festejo, esa nación y ese Estado no habían aún establecido ninguna otra festividad cívica. ${ }^{3}$

Una vez finalizada en 1857, el presidente Juan Rafael Mora trató de poner en marcha políticas de memoria en relación con la guerra antifilibustera que incluían efemérides y monumentos, además de varias formas de exaltación de su propia persona en su condición de máximo conductor de la lucha; pero tales políticas fueron abortadas por la coyuntura política de esos años que culminó con su derrocamiento en 1859 y su fusilamiento en $1860 .{ }^{4}$ Las políticas de memoria concebidas por el presidente Mora fueron retomadas y llevadas a la práctica por los liberales en la segunda mitad de la década de 1880, cuando, como ya se dijo, el Estado ya estaba consolidado y la nación ya había sido inventada y empezaba a ser propagandizada en el conjunto de la población por medio de la educación primaria, según la representación de un país excepcional, un «lugar distinguido entre los pueblos más civilizados». ${ }^{5}$

Aunque Mora no fue el artífice de la fabricación de Juan Santamaría como el héroe popular de la guerra contra Walker, sí había sido clave en proponer el 11 de abril de 1856 como fecha memorable, día en el cual las tropas costarricenses se enfrentaron en una sangrienta batalla contra los filibusteros en la ciudad de Rivas en el sur de Nicaragua. Este combate fue convertido por Mora en mítica victoria cuando en realidad se trató más

3. Díaz, David, La fiesta de la independencia en Costa Rica, 1821-1921, San José, EUCR, 2007.

4. Acuña, Víctor H., «Costa Rica: la fabricación de Juan Rafael Mora (siglos XIX-XXI)», Diálogos. Revista de Historia (UCR), n. ${ }^{\circ}$ 16, 2015, pp. 39-76.

5. «Sección Editorial», La Gaceta. Diario Oficial, 15 de setiembre de 1891, p. 1044. Este editorial se refiere al 70 aniversario de la independencia de Costa Rica. Alaba el «adelanto moral y material» alcanzado por el país en esas siete décadas. Una formulación similar aparece veinte años antes en un artículo de opinión publicado por ese mismo periódico el 16 de setiembre de 1871. Citado en Díaz, David, La fiesta de la independencia..., cit., pp. 60-61. 
bien de un agónico empate, en el cual fue determinante, al parecer, la acción y el sacrificio heroicos de Juan Santamaría, humilde soldado oriundo de la ciudad de Alajuela. ${ }^{6}$ Ahora bien, dado que el festejo del 15 de setiembre ya estaba bien implantado en el seno de la población costarricense al gobierno le pareció lógico y oportuno realizar la develación de la estatua del héroe de Rivas en esa fecha del año 1891. En opinión de La Gaceta, fue una «coincidencia feliz y deliberada». ${ }^{7}$

A comienzos de la década de 1890, los estados y las sociedades en Centroamérica reconocían el peso indiscutible de Estados Unidos, el «gran vecino del norte», pero aparentemente apenas empezaban a percibirlo como una realidad amenazante. Por su parte, a esas alturas, era clara la conciencia del imperio en ascenso de la importancia geoestratégica del istmo centroamericano y de su necesaria función como lugar donde habría de construirse un canal interoceánico. De igual manera, el secretario de Estado James Blaine, había lanzado la iniciativa del panamericanismo, en 1889. También, en 1891, se discutía en el Congreso estadounidense y en el seno de los gobiernos latinoamericanos la necesidad y conveniencia de desarrollar las relaciones comerciales entre las partes y combatir las políticas proteccionistas agresivas promovidas por algunos intereses estadounidenses. ${ }^{8}$

Posiblemente, tales circunstancias se manifestaron en los festejos de inauguración de la estatua del héroe alajuelense. ${ }^{9}$ Así, las ceremonias tuvieron más bien preocupaciones de política interna y de política centroamericana. Sin ser excesivamente expresivas, estas actividades recordaron en distintos momentos el carácter centroamericano de la guerra contra los filibusteros de William Walker y el papel solidario de Costa Rica con su vecina Nicaragua. Camilo Mora, ante la invitación formal del gobierno para que participase como invitado de honor en los festejos, en representación de su padre Juan Rafael Mora y de su tío José Joaquín Mora, respondió afirmativamente y se definió como «hijo de

6. Esta condición social del héroe, «humilde hijo del pueblo» y «oscuro soldado» fue subrayada por la prensa y por quienes pronunciaron los discursos oficiales durante las ceremonias; véase: «Discurso pronunciado en el acto de la inauguración del monumento a Juan Santamaría por el señor Ministro de la Guerra, don Rafael Iglesias, á nombre y en representación del Gobierno», La Gaceta. Diario Oficial, 18 de setiembre de 1891, pp. 1052-1053 (igualmente reproducido en La Prensa Libre, 19 de setiembre de 1891, p. 4; y también «Sección Editorial, La inauguración de la estatua de Juan Santamaría, en Alajuela, el 15 de setiembre de 1891», Ibidem, p. 1052.

7. Véase, supra, nota 5.

8. Véase el editorial: «La tarifa Mc. Kinley y el Gobierno de Costa Rica», La Prensa Libre, 18 de noviembre de 1891, p. 2.

9. Para una mirada de conjunto de la celebración, véase: Fumero, Patricia, «La celebración del santo de la patria: la develización de la estatua del héroe nacional costarricense, Juan Santamaría, el 15 de setiembre de 1891», en Enríquez, Francisco e Iván Molina (ed.), Fin de siglo XIX e identidad nacional en México y Centroamérica, Alajuela, Museo Histórico Cultural Juan Santamaría, 2000, pp. 403-435. Según la autora la idea de erigir el monumento surgió de una iniciativa local acogida por el gobierno, el cual convocó a una colecta de fondos para financiar la obra, pero como estos no fueron suficientes el gobierno puso 5.000 pesos. Como desde siempre había circulado la duda sobre la veracidad del acto heroico de Santamaría, la ocasión fue aprovechada para confirmarla mediante una recopilación formal de testimonios de quienes presenciaron el acto y la muerte de quien en Alajuela era llamado El Erizo, por su condición de mulato. En fin, Fumero subraya con razón el papel de la prensa en el surgimiento y organización del festejo. También David Díaz se refiere a esta celebración en La fiesta de la independencia..., cit., pp. 115-124. 
Centroamérica». ${ }^{10}$ No obstante, en las ceremonias no hubo una representación oficial de las otras repúblicas centroamericanas como sí ocurrió cuatro años después en 1895.

El elemento contextual dominante de la celebración fue la situación política interna de Costa Rica, gobernada autoritariamente por un presidente que había suspendido las garantías individuales y había enviado al exilio a varios de sus opositores. No en vano, el gobernante decretó una amnistía para los perseguidos políticos y la prensa afín al régimen insistió en que las ceremonias habían sido expresión de unidad y concordia nacionales, por encima de banderías políticas. ${ }^{11}$ Sin embargo, al lado de los actos oficiales celebrados en la plaza creada al efecto para colocar la estatua, se desarrolló un evento con participación de los artesanos que fue obstaculizado e interrumpido por la policía. ${ }^{12}$ Aquí se manifestó embrionariamente, un fenómeno que maduró en las dos primeras décadas del siglo siguiente, es decir, la iniciativa y la participación de sectores de la sociedad civil en este tipo de festejos.

De todos modos, las celebraciones del 15 de setiembre de 1891 fueron esencialmente oficiales u gubernamentales, apoyadas por la corporación municipal de Alajuela, acorde con lo que había sido programado. Además, de oficiales los festejos fueron esencialmente laicos, ya que no tuvieron ninguna ceremonia religiosa, aunque la jerarquía eclesiástica formó parte de los dignatarios oficiantes. El evento fue también oficial porque el pueblo, que según la prensa asistió en masa los dos días de festejos, la víspera y el propio 15 de setiembre, fungió solamente como espectador del ritual oficial y de los actos que le fueron obsequiados, en especial los fuegos de artificio, la elevación de globos y los conciertos de las bandas militares. ${ }^{13}$ La excepción habría sido la citada «tribuna popular», como la llama Fumero, reprimida por la policía. Sin embargo, se debe señalar que uno de los componentes destacados de la conmemoración, fueron «los inválidos», es decir, los veteranos de guerra, aunque ninguno de ellos fue invitado a dirigir un discurso en los actos de los festejos.

El cronista estrella de las ceremonias fue el poeta Rubén Darío, a la sazón radicado en Costa Rica, redactor del diario La Prensa Libre. En sus crónicas de la celebración, floridas y más bien inocuas y triviales, denomina «yankees» a los filibusteros. ${ }^{14}$ De igual manera, en su contribución al número especial de El Heraldo del 15 de setiembre de

10. Véase: «Secretaría de Guerra y Marina. Cartera de Guerra», La Gaceta. Diario Oficial, 18 de setiembre de 1891, p. 1051.

11. El decreto de amnistía aparece en, «Sección oficial. Poder Ejecutivo. N. 9», La Gaceta. Diario Oficial, 18 de setiembre de 1891, p. 1.

12. Véase Fumero, Patricia, «La celebración del santo de la patria..., cit., pp. 423-424. Véase también, «La gran apoteosis», El Heraldo, 20 de setiembre de 1891, p. 2, donde aparece una breve referencia a este incidente.

13. «Programa oficial para la inauguración de la estatua de "Juan Santamaría” (sic)». La Gaceta. Diario Oficial. 11 de setiembre de 1891, p. 1031. Véase también «Sección Editorial», Ibidem.

14. Rubén Darío, «Fiesta de la patria», La Prensa Libre, 22 de setiembre de 1891, p. 2. Así se expresa el célebre poeta: «[el] tambor Santamaría, aquel que dio fuego al Mesón, allá en Rivas, cuando los yankees, cuando fuimos librados del extranjero invasor.» Como se observa, prefiere al de filibusteros el gentilicio «yankees». 
1891, el poeta nicaragüense llama a los hombres de Walker «cazadores yankees». ${ }^{15}$ En este mismo número, Juan María Murillo, personaje que no sabría identificar, afirma que en aquel momento la autonomía centroamericana estaba amenazada por «el Águila del Norte». ${ }^{16}$ También un bardo local dedica unos versos al héroe en donde dice: «Al sordo chirrido del mechón / La yama (sic) ligera va corriendo; / De terror los yankes (sic) salen huyendo...». ${ }^{17}$ La revista Costa Rica Ilustrada publicó una edición en homenaje de Juan Santamaría en la cual incluyó algunos documentos oficiales, los primeros textos que rescataron su figura, varias poesías y algunos ensayos breves. Entre ellos está el discurso pronunciado por Ramón Loría el día de la celebración en el cual se refiere al invasor como «orgulloso yankee». ${ }^{18}$ Por último, Salvador Jirón, encargado por la Municipalidad de Puntarenas de dar un discurso en la celebración del 15 de setiembre de 1891 en dicho puerto, se pregunta: «¿Qué fuera hoy este continente si la chispa voraz del yanke (sic) abrasa nuestra existencia libre?» Con esta pregunta, el orador pretende darle estatura americana al héroe local costarricense. ${ }^{19}$

Estas especificaciones del lugar de donde provenía el peligro filibustero son más bien excepcionales en un mar de discursos centrados en la celebración del héroe, en la afirmación de su existencia como persona real y no mítica, y en la caracterización de la guerra contra los filibusteros como verdadera segunda independencia de Costa Rica y Centroamérica. En su mayoría, quienes se refieren a la guerra prefieren separar al filibustero William Walker de las políticas expansionistas del gobierno estadounidense. Tal ejercicio retórico es posible que sea expresión de prudencia de los representantes del gobierno; discreción a la cual no se sienten obligados periodistas, escritores y oradores menos ilustres. Posiblemente, ese silencio también sea muestra de una percepción aún indefinida de los riesgos que conllevaba tener un vecino tan poderoso y tan ambicioso. ${ }^{20}$

15. El Heraldo, Número extraordinario, «Apoteosis de Juan Santamaría», 15 de setiembre de 1891, p. 2. En este número aparecen contribuciones de destacados políticos e intelectuales liberales costarricenses, entre ellos los futuros presidentes de la República, Rafael Iglesias, Cleto González y Ricardo Jiménez, y de tres escritores nicaragüenses radicados en el país: Pedro Ortiz, Enrique Guzmán y Rubén Darío.

16. Ibidem, p. 4.

17. Juan Bonilla C., «Remitidos. A Juan Santamaría», La Gaceta. Diario Oficial, 15 de setiembre de 1891, p. 3 .

18. Ramón Loría, «Discurso que por encargo de la Municipalidad de Alajuela fue escrito para pronunciarlo el 15 de setiembre de 1891», Costa Rica Ilustrada. Revista de Ciencias, Artes y Literatura, n. ${ }^{\circ}$ 34, 15 de setiembre de 1891, p. 271.

19. El Heraldo, 23 de setiembre de 1891, p. 2.

20. No obstante, Costa Rica estaba ya aprendiendo a lidiar con una de las dimensiones de la relación imperial, es decir, la inversión extranjera. En efecto, en diciembre de 1890 había entrado triunfante a la capital el primer tren procedente de puerto Limón. La obra había sido realizada por el empresario estadounidense Minor C. Keith. En Costa Rica, el ferrocarril que comunicaba al fin la capital y las otras ciudades de la región central con el puerto del Caribe fue recibido con gran entusiasmo como emisario del progreso, pero menos de un año después en la prensa y en los círculos gubernamentales ya se multiplicaban las quejas sobre el mal estado de la vía férrea y del material rodante; véase: «Reunión de notables», La Prensa Libre, 12 de noviembre de 1891, p. 2. 
En suma, estos festejos fueron marcados por la coyuntura local, es decir, por la voluntad gubernamental de bajar la tensión política, y por una intención de fraternidad centroamericana; la llegada del imperio no fungía aún como telón de fondo de la fiesta cívica. No obstante, con la inauguración del monumento de Juan Santamaría es claro que el Estado costarricense ha puesto en marcha una política de memoria sistemática con la guerra de 1856-1857 contra William Walker como tema central, para reivindicar su condición de país independiente y soberano, en la cual habrá que lidiar con la cuestión de la responsabilidad, la simpatía el apoyo o no, del gobierno estadounidense a las andanzas del filibustero.

\section{La celebración del IV centenario del «descubrimiento de América», 1892}

Como es conocido esta celebración fue promovida desde España, en especial por la Unión Iberoamericana, fundada en 1885, y asumida por los distintos gobiernos latinoamericanos. ${ }^{21}$ El gobierno de Costa Rica se sumó a los festejos, pero ciertamente no con la energía y la voluntad de la celebración, del héroe nacional Juan Santamaría, un año antes. Es posible que haya influido en el poco brillo de la fiesta la coyuntura política interna ya señalada, dominada por un gobierno autoritario que había cerrado el parlamento y que se encontraba enfrascado en un grave conflicto con la jerarquía eclesiástica y con el clero en general, agrupados en torno a un partido de orientación clerical llamado Unión Católica. ${ }^{22}$

La fiesta oficial mantuvo un formato similar al del año anterior, pero con dos particularidades. No hubo discursos oficiales los dos días de festejos, de modo que no es posible saber la posición de las autoridades respecto del significado que conferían al evento. ${ }^{23}$ Hubo únicamente una pequeña nota editorial en el diario de gobierno titulada «Colón» consagrada a exaltar su figura. ${ }^{24}$ No obstante, el gobierno trató de mostrar su compromiso mediante un decreto que estableció: «Declárase a perpetuidad fiesta nacional de la República el día 12 de Octubre.» La justificación de esta decisión fue dar «testimonio de admiración y de respeto a la memoria de Cristóbal Colón, y para perpetuar el recuerdo de la fecha gloriosa del descubrimiento de América». ${ }^{25}$ Como se observa, se celebra a

21. Sobre los orígenes de las celebraciones del IV Centenario, 1892, véase: Rodríguez, Miguel, Celebración de «la raza»: una historia comparativa del 12 de octubre, México, Universidad Iberoamericana, 2004, pp. 2330 y Marcilhacy, David, Raza hispana. Hispanoamericanismo e imaginario nacional en la España de la Restauración, Madrid, Centro de Estudios Políticos y Constitucionales, 2010, pp. 327-334.

22. Pocos días antes de la celebración, la prensa se preguntaba que haría el gobierno: «En toda la América, se hacen grandes preparativos para celebrar pomposamente el Centenario de Colón. ¿Qué hará el Gobierno de Costa Rica para la celebración de tan magno acontecimiento?», La República, 4 de octubre de 1892, p. 2.

23. «Programa para la celebración del 4. ${ }^{\circ}$ centenario del descubrimiento de América», La Gaceta. Diario Oficial, 11 de octubre de 1892, p. 1216. Dicho programa aparece como así realizado en Prensa Libre, 13 de octubre de 1892, p. 1. Según esta nota, al final de los actos en la Casa Presidencial «hubo una recepción y en seguida (sic) se libó una copa a la gloria de Colón y al progreso de América.»

24. «Sección Editorial. COLON», La Gaceta. Diario Oficial, 12 de octubre de 1892, p. 1222.

25. «Sección Oficial. Poder Ejecutivo. n. ${ }^{\circ} 13 »$, Ibidem, p. 1219. 
Colón y a su realización, pero no se exalta explícitamente a España, ni a la «raza hispana». Esto mismo se observa en algunas publicaciones aparecidas en la prensa comercial. Así, por ejemplo, un destacado intelectual salvadoreño pide que el Nuevo Mundo sea llamado «Colombia» y no América a fin de reparar esa terrible confusión e injusticia. ${ }^{26}$

El otro elemento que diferencia este festejo del de Juan Santamaría es que la ceremonia principal fue un Te Deum en la catedral de San José, no un acto cívico de las autoridades de gobierno. Un ceremonial que remite a los primeros años de vida independiente en la transición de colonia a república. El acto religioso estuvo marcado por el conflicto entre las autoridades civiles y eclesiásticas, ya que el obispo de San José ostensiblemente hizo abandono de la catedral antes de que ingresase al templo el presidente de la República. Previamente, el obispo había oficiado una ceremonia en honor de la celebración y había consagrado la Diócesis al Corazón de Jesús. ${ }^{27}$ Además, el clima se confabuló contra los festejos, de modo que un diluvio impidió la realización de los fuegos de artificio al atardecer del día 12. No obstante, el pueblo capitalino recibió satisfacción cuatro días después, el 16, cuando se pudo efectuar el juego de pólvora pospuesto. ${ }^{28}$

Aparte de la fiesta oficial, hubo otras actividades de celebración del centenario. La prensa tomó iniciativas al respecto, como reproducir documentos colombinos y publicar cables sobre los festejos en España y otros países, y, además, informó de eventos realizados por personas privadas en la capital y de ceremonias realizadas fuera de ella. Así, la sociedad «Los Estudiantes» organizó «un certamen lírico literario» para conmemorar el cuarto centenario. Por su parte, la Sociedad de Artes y Oficios celebró al mismo tiempo su tercer aniversario y un tributo a Colón. ${ }^{29}$ Además, en «muchas casas de nacionales y españoles, se enarbolaron banderas y se alumbró el frente en las noches» de los dos días de festejos y un grupo de personas de «sociedad», es decir de la clase alta, organizó un baile. Aparentemente, el evento de mayor animación fue un banquete en un restaurante muy frecuentado por la colonia española. ${ }^{30} \mathrm{El}$ papel de las colonias españolas en estas celebraciones en los distintos países hispanoamericanos es conocido. Interesante que la prensa no informara de la participación de la colonia italiana en estas fiestas.

26. David Joaquín Guzmán, «El gran día de América», Prensa Libre, 12 de octubre de 1892, p. 1. Se trata de un artículo tomado de otra publicación, la cual no es indicada. El mismo argumento es repetido por otro articulista al día siguiente en el mismo diario, véase: S. Jaramillo, «1892. A Cristóbal Colón», Prensa Libre, 13 de octubre de 1892, p. 1. Es el mismo diario ya citado como La Prensa Libre que modificó su nombre en junio de 1892 .

27. «Ayer dio origen a muchos comentarios que el señor Obispo no aguardara en la Catedral al señor Presidente ni tomara parte en el Te Deum ni pronunciara el sermón de que se habían hecho anuncios, sino que con cierta ostentación salió del templo poco antes de llegar el señor Rodríguez. Unos atribuían su conducta a la poca disposición que presenta el Gobierno de complacer al Clero en lo del nombramiento de maestros, otros a diferentes causas; pero en lo que convenían todos es en que el (sic) Iglesia y el Estado no hacen por el momento buenas migas. Es de apetecerse que se aclare el misterio para que el país vea a tiempo y bien el asunto que tanto le importa.» «Notas varias», La República, 14 de octubre de 1892, p. 2.

28. «Anuncios. Aviso». «Los fuegos artificiales anunciados para el 12 del corriente, tendrán lugar hoy a las 5 p. m. en el Parque Morazán si el tiempo la permite», La Gaceta. Diario Oficial, 12 de octubre de 1892, p. 1219.

29. Prensa Libre, 15 de octubre de 1892, p. 1, en donde se informa de ambos eventos.

30. «Notas varias», La República, 14 de octubre de 1892, p. 2. 
Como se adelantó, hubo festejos fuera de la capital. En la muy católica Cartago, por iniciativa del gobernador de la provincia, se celebró un acto oficial en el palacio municipal, precedido de un Te Deum cantado «por el ingreso de la virgen América al seno de la familia cristiana, verificado hoy hace cuatro siglos». Según se infiere de la crónica periodística, el evento se centró en rendir homenaje a Colón, como emisario de la cristiandad. ${ }^{31}$ En la ciudad de Alajuela fueron convocados los festejos por el gobernador de la provincia y la municipalidad de esa ciudad, con un formato similar a los realizados en San José. No obstante, aquí se pronunciaron discursos y hubo un desfile con la banda militar. El cronista de estos eventos lamentablemente no dice nada sobre los discursos, salvo alabarlos. $^{32}$

La prensa informó también de dos celebraciones realizadas fuera de la región central de Costa Rica, una en Cañas, provincia de Guanacaste, y otra en Esparta (hoy Esparza), en la provincia de Puntarenas. En el caso de la primera, el corresponsal señala que los vecinos rindieron homenaje al «gran conquistador» que trajo «la civilización». En la actividad tuvieron participación destacada los escolares. Como en la capital, en el acto religioso se consagró la parroquia al Corazón de Jesús. Pero de estos festejos, lo que más llama la atención es que hubo «un baile de indios compuesto de jóvenes de ambos sexos»; lo que esto fue no es explicado y me permito especular que quizás se trató de una danza de moros y cristianos, de origen colonial. Pareciera que la celebración escenificó el regocijo de los «bárbaros» por la llegada de la «civilización». ${ }^{33}$ En Esparta, hubo un conflicto entre los vecinos y el cura parroquial, quien decidió, con la complicidad de una parte del concejo, consagrar el edificio municipal al Corazón de Jesús. A pesar de este incidente, tanto las autoridades eclesiásticas, sin la participación del cura «fanático» como el pueblo rindieron homenaje «al inspirado genio de Colón». ${ }^{34}$

Llama la atención un artículo de opinión publicado en La República. ${ }^{35}$ En él se hace un balance muy crítico y muy pesimista de los países hispanoamericanos. «España, Italia, Estados Unidos pueden regocijarse el gran día, pueden mirar de frente a frente la dulce claridad del alba y los rayos esplendentes del sol. Hispanoamérica no. Porque en vez de civilizar al indio, se ampara a su desnudez y excusa con su ignorancia, la molicie y el atraso en que la sorprende el siglo V de su vida.» Luego agrega «Nuestros pueblos de hispanoamérica (sic) que, en su mayor parte son pueblo de raza europea, padecen atrofia de la voluntad y se mueren sin brújula y sin luz en el Océano de la vida.» Pretenden llamarse «países jóvenes», pero por sus taras son más bien «viejos-niños».

Este pesimismo histórico respecto de los pueblos hispanoamericanos es detectable en la prensa costarricense en las décadas siguientes en el contexto del ascenso imperial de

31. El corresponsal. «Correspondencia. Cartago, Oct. 12 de 1892», Prensa Libre, 14 de octubre de 1892, p. 1.

32. «Alajuela. De nuestro corresponsal», La República, 15 de octubre de 1892, p. 2.

33. A. G. Ug., «Celebración del Cuarto Centenario de Colón», La República, 19 de octubre de 1892, p. 2.

34. «Entusiasmo fanático», La República, 26 de octubre de 1896, p. 2

35. «Viejos-Niños», La República, 11 de octubre de 1892, p. 2. Posiblemente, cuando este texto fue escrito aún no estaba claro si se festejaría el IV Centenario. 
Estados Unidos y, en especial, tras la debacle española de 1898. Usualmente se intenta excluir a Costa Rica de tal condena, ya que es un país «excepcional». Por eso sorprende que en este texto se diga: «En Costa Rica no será celebrado el 12 de Octubre. La fiesta tendría que ser excepcionalmente hermosa, teniendo por base mucha prosperidad, mucha cultura y firmes instituciones políticas. Nada de eso pude (sic) ofrendar al hombre extraordinario que la descubrió en el día de su apoteosis, calle pues; sirva ese silencio para su enmienda al menos.» Posiblemente, la decepción y amargura que aquí se expresan sirven para condenar en forma oblicua el régimen autoritario imperante en el país. ${ }^{36}$

De todos modos, en las primeras décadas del siglo Xx, en el contexto del ascenso de Estados Unidos como imperio, en distintas ocasiones habrá una confrontación entre este pesimismo histórico y una mirada más optimista de las posibilidades de los pueblos latinoamericanos para abandonar sus rémoras e inercias que los condenan a ser fácil presa de los apetitos de dominación de la «raza anglosajona». No obstante, en 1892, aún no se trata del «día de la raza», ni de la lucha entre la «raza latina» y la «raza anglosajona». El «peligro yankee», aún no se nombra, pero se reconoce la pujanza y la solidez de las «instituciones republicanas» estadounidenses, en contraste con la vida de los «hijos de Colón».

En fin, los festejos del cuarto centenario sirvieron para subrayar la herencia hispánica como matriz de la identidad costarricense. En efecto, a la ya establecida representación de Costa Rica como nación excepcional se ajustaba muy bien la reivindicación de su fondo hispánico, europeo y de raza blanca. En suma, las ceremonias del IV Centenario en Costa Rica fueron realizadas en forma modesta y con no mucho entusiasmo por parte de las autoridades gubernamentales. Aparentemente, quienes expresaron más regocijo fueron las personas integrantes de la colonia española, un fenómeno similar observado en los festejos de otros países latinoamericanos, según ha sido señalado por los ya citados Rodríguez y Marcilhacy. En ellas estuvo muy presente el ceremonial religioso en donde el homenaje al Almirante se mezcló con la consagración del Corazón de Jesús. ${ }^{37}$

\section{La inauguración del Monumento Nacional, en $1895^{38}$}

Dentro del kit memorial elaborado por el propio Juan Rafael Mora durante y después de los acontecimientos estaba incluida la erección de una estatua en homenaje a la guerra

36. Este pesimismo contrasta con un discurso pronunciado, un año antes, en los festejos de inauguración de la estatua de Juan Santamaría por un representante del gobierno municipal alajuelense quien, en un pasaje de exaltación de quienes combatieron a Walker, los puso en relación con las glorias de la «Madre España». «Discurso de don J. Marcelino Pacheco, a nombre de y en representación de la Municipalidad de Alajuela», La Gaceta. Diario Oficial, 19 de setiembre de 1891, p. 1057.

37. Desconozco la razón de esas consagraciones el 12 de octubre, aunque Carmela Velázquez, colega historiadora de las devociones, me señaló que España estaba consagrada al Corazón de Jesús, hipotética explicación.

38. Las fiestas del 15 de septiembre de 1895. Celebradas con motivo de la inauguración del Monumento Nacional erigido en San José a los héroes del 56 y 57, (Edición ordenada por el Gobierno de la República), San 
contra los filibusteros. La iniciativa fue retomada por los liberales, en el gobierno del presidente Bernardo Soto, en 1888. El monumento que simbolizaba la victoria de las cinco hermanas centroamericanas sobre el filibustero fue inaugurado con pompa y circunstancia el 15 de septiembre de 1895 por el presidente Rafael Iglesias. La nota característica de las ceremonias de este evento oficial es lo que podríamos llamar la apoteosis de Mora. A partir de 1895, en el plano de las políticas de memoria del Estado y de las elites costarricenses, el olvido y las negaciones en relación con Mora van a desaparecer, a costa de algunas omisiones y silencios con respecto a su trayectoria histórica.

Las ceremonias de inauguración del monumento estuvieron dominadas por los honores que se le rindieron a Juan Rafael Mora, a José Joaquín Mora, a José María Cañas y a los oficiales y soldados veteranos de la guerra, todos los cuales recibieron condecoraciones. Camilo Mora recibió la de su padre y la de su tío, y Rafael Cañas, la de su padre; como se dijo, ambos ya habían sido invitados de honor en la ceremonia de 1891. Este acto simbólico parece expresar la voluntad de la llamada oligarquía cafetalera de superar sus divisiones heredadas tras el fusilamiento de Mora y Cañas en 1860. Al respecto es sintomático que en todos los textos publicados en este álbum no hay una sola palabra sobre este suceso y, en general, nada sobre el lado menos luminoso de Mora como gobernante. $^{39}$

Las ceremonias tuvieron un carácter totalmente oficial, orquestadas y presididas por el gobierno costarricense, y los militares con sus bandas, paradas y tiros al blanco fueron los principales protagonistas. Conviene agregar que, para subrayar el carácter oficial de estos eventos, estuvieron presentes delegados de los gobiernos de los otros países centroamericanos. No hubo participación directa de sectores de la sociedad civil, salvo el Colegio de Abogados y la Facultad de Medicina.

Algunos escolares y colegiales participaron en el acto cívico principal del 15 de septiembre, ya que, según se consigna en el programa, la «Compañía de Infantería» de estudiantes del Liceo de Costa Rica encabezó el desfile con una «banda de clarines» y los himnos nacionales de los países centroamericanos fueron entonados por alumnos de las escuelas de varones de San José. Además, los delegados extranjeros visitaron los principales centros educativos de la capital y muchachas colegiales participaron en un evento el

José, Tipografía Nacional, 1897. Véase también el útil y documentado estudio de Patricia Fumero, El Monumento Nacional. Fiesta y develización, setiembre de 1895, Alajuela, Museo Histórico Cultural Juan Santamaría, 1998. Sobre estas y otras ceremonias, véase Díaz, David, «Fiesta e imaginería cívica: la memoria de la estatuaria de las celebraciones patrias costarricenses, 1876-1921», Revista de Historia (UNA-UCR), 49-50, 2004, pp. 111-154. También de este autor véase, La fiesta de la independencia..., cit., pp. 129-134.

39. El libro conmemorativo de estos eventos refleja bien lo que fueron las ceremonias y algunos de los textos que incluye expresan esa apoteosis de Mora; por ejemplo, la breve historia de la campaña contra los filibusteros de Joaquín Bernardo Calvo con la cual se abre el volumen, y que presenta en forma sintética la versión costarricense de la guerra, versión, establecida en sus líneas centrales por el propio Mora; y la colección de documentos casi todos producidos por Mora durante los eventos de la guerra, que aparece como apéndice al final del volumen. También el discurso de Antonio Zambrana, famoso orador de la época de origen cubano, pronunciado en un acto de conmemoración de la guerra, realizado el 1 de mayo de 1895, reproduce la versión costarricense de la guerra. 
12 de septiembre en el cual cantaron los himnos de las repúblicas centroamericanas. ${ }^{40}$ En todo caso, las ceremonias tuvieron un tinte eminentemente militar y las personas del público en general, fungieron únicamente como espectadores. ${ }^{41}$

Los festejos realizados los días 13, 14 y 15 tuvieron un carácter laico y civil y no hubo ninguna ceremonia religiosa, aunque en la comitiva oficial de todos los actos estuvieron presentes el obispo y las principales autoridades eclesiásticas. Además, de los tradicionales fuegos de artificio y conciertos de bandas para el pueblo, y de los bailes exclusivos para la clase alta, hubo funciones teatrales con una compañía española. Dentro del ritual oficial conviene singularizar el acto de rendir homenaje a las colonias extranjeras, por su participación en la lucha contra los filibusteros; pero también porque Costa Rica, según dijo el presidente Iglesias, valoraba su contribución al progreso del país desde entonces y en el momento presente. Gracias a sus vínculos externos, esta nación «se ha puesto en pie y ha marchado resuelta a la conquista de prósperos destinos». ${ }^{42}$

Aparte de la apoteosis de Mora y de la exaltación oficial de la nación costarricense, las ceremonias de 1895 estuvieron marcadas por una atmósfera y una intención centroamericanistas. La iconografía y el lenguaje simbólico del conjunto escultórico del monumento dan testimonio de esa voluntad de conjuntar a los estados centroamericanos. En las ceremonias y en el libro no hay referencia alguna a Estados Unidos y no se vincula a Walker con ese país. No obstante, en un artículo de opinión en la prensa la unidad italiana y la alemana fueron invocadas como ejemplos para Centroamérica, ya que la unificación es un remedio contra «la ambición de estados vecinos». ${ }^{43}$ Quizás esta frase oblicua podría tomarse como una alusión a Estados Unidos, en un momento anterior a la guerra hispano-estadounidense de 1898 y a la difusión de las ideas antiimperialistas y del arielismo.

En este sentido, los festejos fueron una autocelebración del Estado y la nación costarricenses delante de los otros países centroamericanos cuyos delegados fungieron como testigos. Así, por ejemplo, es significativa la excursión de tres días que esos delegados hicieron a puerto Limón y a algunas plantaciones bananeras en la zona. Era una forma de mostrar el adelanto del país en relación con sus vecinos del Istmo y la promesa que abría la naciente actividad bananera. ${ }^{44}$ Por cierto, que los visitantes fueron atendidos por el propio Keith y por altos funcionarios de la Compañía Bananera. Ese mismo espíritu de

40. «Actualidades», La República, 12 de setiembre de 1895, pp. 2-3; programa de la fiesta en honor de las delegaciones centroamericanas en el Colegio Superior de Señoritas, con la participación de niñas escolares.

41. «Programa de la fiesta nacional que se celebrará con motivo de la inauguración del monumento erigido en esta capital en memoria de los triunfos alcanzados en las campañas de los años 1856 y 1857 y del LXXIV aniversario de la independencia de Centroamérica», La Gaceta. Diario Oficial, 11 de setiembre de 1895, pp. 904-905.

42. «Discurso pronunciado por el Señor Presidente de la República en el acto de condecorar a los cónsules extranjeros, el día 14 de setiembre de 1895», La Gaceta. Diario Oficial, 18 de setiembre de 1895, pp. 920921.

43. «Fiestas centroamericanas», La República, 4 de setiembre de 1895, p. 2.

44. «Sección Editorial», La Gaceta. Diario Oficial, 12 de setiembre de 1895, pp. 908-909. Aquí se hace una crónica de esa visita a Limón. 
autocongratulación se manifiesta en una entrevista que le hizo Aquileo J. Echeverría, afamado poeta local, al delegado de El Salvador en la cual le solicitó sus impresiones sobre Costa Rica. El diplomático respondió que se llevaba muy buena opinión de la organización política y del sistema de educación primaria del país. Además, manifestó que le llamó la atención el orden y la moderación con las cuales el pueblo se condujo durante los festejos. «Parecía — dijo- que estábamos entre gentes de otra raza.» ${ }^{45}$

Sobran los comentarios, aunque cabe agregar que la prensa y el diario oficial también abundaron en el tema de la cordura con que el pueblo se comportó. No obstante, la morigeración quizás no fue tan espontánea, ya que el gobernador de la provincia de San José instruyó formalmente al jefe de la policía de la capital para que durante los festejos con el fin de resguardar «el mayor orden y compostura» prohibiese «que se grite en las calles y parajes públicos, como indebidamente se ha hecho en tiempos de fiestas cívicas». Aquellos que irrespetasen esta disposición serían sancionados. ${ }^{46}$ En suma, una nación imbuida de sus atributos excepcionales rubricó la memoria de su lucha exitosa contra los filibusteros, aunque como en 1891 la eventual relación entre esos agentes privados y las políticas oficiales estadounidenses, pasadas y presentes, quedó en silencio. Quizás, fuese esa una manera de conjurar el realce que ya tomaba la presencia de la potencia en el Istmo centroamericano. Al mismo tiempo, la celebración pretendió abrir las puertas para ir al reencuentro de la perdida unidad centroamericana, de necesidad frente a futuros riesgos del entorno internacional, aunque debe advertirse que en ningún momento se invocó el espíritu de Francisco Morazán, cuyo centenario de nacimiento había ocurrido tres años atrás. ${ }^{47}$

\section{Los festejos del centenario del «grito de la independencia», en 1911}

Como ahora se verá, el paisaje de la conmemoración cambió profundamente al iniciarse el siglo Xx. En efecto, tres lustros después de los festejos de inauguración del Monumento Nacional en San José, Costa Rica celebró el llamado centenario del grito de la independencia de San Salvador, del 5 de noviembre de 1811, como eco y complemento de los grandes festejos que en esta ocasión organizó la República de El Salvador. Costa Rica y los otros países centroamericanos, salvo Nicaragua enviaron delegados a los magnos eventos realizados en la capital salvadoreña. La dimensión centroamericana de los festejos salvadoreños recuerda las ceremonias de 1895 que contaron con la presencia de representantes de los otros países centroamericanos; pero lo que parece original en el caso de 1911 es que en San José se intentó replicar en menor escala lo que acontecía en El Salvador. En esta circunstancia las fiestas sirvieron para subrayar la relación especial

45. Aquileo J. Echeverría, «Sección Política. Reportaje. Una visita al señor delegado por El Salvador», La República, 22 de setiembre de 1895, pp. 2-3

46. La Gaceta. Diario Oficial, 13 de setiembre de 1895, p. 912.

47. Sobre la construcción heroica del caudillo unionista, véase: Lacaze, Catherine, Francisco Morazán. Le Bolivar de l'Amérique Centrale, Rennes, Presses Universitaires de Rennes, 2018. 
entre ambos países, un fenómeno efectivamente observable en las primeras décadas del siglo Xx. Posiblemente, dicho vínculo especial tenga alguna relación con la circunstancia de que en esos momentos ambos países junto con los otros del Istmo ya estaban insertos en el sistema de estados clientes establecido por Estados Unidos en el Caribe y América Central, una década atrás. Dentro de este encuadre, estos dos países que se profesaban tanta amistad eran, junto con Guatemala, los que manejaban un mayor margen de autonomía frente a la potencia imperial, la cual había impuesto un protectorado en Panamá y estaba en camino de establecerlo en Nicaragua. Habría que agregar que los gobiernos de ambos países eran afines en su enemistad con el régimen del dictador guatemalteco, $\mathrm{Ma}$ nuel Estrada Cabrera. Este era el nuevo contexto de la relación imperial; si en 1895 Estados Unidos estaba llegando, en 1911 ya había llegado y se había bien instalado en la región centroamericana.

También la forma de las conmemoraciones se había modificado profundamente producto del ascenso de una sociedad civil que empezaba a exigir protagonismo en la vida política y también como consecuencia de la aparición en su seno de lo que llama Elizabeth Jelin «emprendedores de la memoria», individuos y agrupaciones, siempre disponibles para organizar y producir, en el sentido escénico del término, todo tipo de actividades cívicas o conmemorativas. ${ }^{48}$ Por tal razón, los festejos de 1911 en la ciudad de San José parecen ser más variados y animados que los de 1895. Se trata, en consecuencia, de fiestas con respaldo oficial, pero cuyo motor son personas y grupos de la sociedad civil.

El motivo de la celebración fue una revuelta antifiscal que estalló en la ciudad de San Salvador el 5 de noviembre de 1811 y que luego encontraría émulo en la ciudad de Granada, Nicaragua. En sentido estricto, lo que ocurrió simplemente fue el derrocamiento de las autoridades representantes de la corona sin que los sublevados pidiesen la independencia de España. No obstante, las elites salvadoreñas y los historiadores del siglo XIX y sus sucesores dedicados al cultivo de la historia patria convirtieron la revuelta antifiscal en movimiento precursor de la independencia. En esas condiciones fue como se celebró el centenario en 1911. El gobierno salvadoreño estableció una comisión oficial a tal efecto, mientras que la celebración costarricense nació en el seno de algunas personas privadas.

La iniciativa fue encabezada por el expresidente de Costa Rica, Cleto González Víquez (1906-1910) fue respaldada por algunos miembros de la intelectualidad liberal y algunos jóvenes profesionales y estudiantes de Derecho, entre los que destacaba Octavio Castro Saborío, un personaje que se va a convertir en un gran emprendedor de la memoria nacional costarricense y en especial, del culto a Juan Rafael Mora. Desde el inicio la propuesta fue acogida por el cónsul de El Salvador en Costa Rica. La comisión organizadora invitó a las colonias extranjeras, los clubes sociales y los círculos de obreros y artesanos a que se sumaran a la festividad. ${ }^{49}$ Como había sido el caso de los festejos previos,

48. Jelin, Elizabeth, Los trabajos de la memoria, Madrid y Buenos Aires, Siglo XXI Editores, 2002.

49. «Los festejos en esta capital con motivo del centenario del grito de independencia», La República, 8 de setiembre de 1911, p. 5 y «Participación que tomarán las corporaciones y colonias en las fiestas de noviembre», La República, 17 de octubre de 1911, p. 8. 
la prensa tuvo una participación destacada en su convocatoria y en forma específica $L a$ República se sumó a la celebración mediante la publicación de un número especial el día del centenario. Dicho número contenía un largo editorial, un relato de los acontecimientos de 1811 del historiador de tiempos de la independencia Alejandro Marure, un manifiesto del presidente salvadoreño convocando a la celebración, y semblanzas de los principales protagonistas del levantamiento de $1811 .^{50}$

Paralelamente a la organización del festejo en Costa Rica, organizaciones de la sociedad civil y corporaciones oficiales nombraron y enviaron representantes a las festividades salvadoreñas. Tal fue el caso de los círculos de estudiantes, los colegios profesionales de abogados, médicos, farmacéuticos y dentistas y las agrupaciones de obreros y artesanos. Estas últimas organizaron una elección con participación de cientos de personas en la cual escogieron a tres delegados. ${ }^{51}$

El formato del festejo siguió el modelo que ya venía de fines del siglo XIX con retreta con bandas militares y actos cívicos oficiales. De igual modo, en esta celebración no hubo ningún acto religioso. Pero aparecieron nuevos componentes, tomados de una nueva forma de festejar el 15 de setiembre, es decir, celebrar el principal acto cívico oficial con presencia de escolares al pie del Monumento Nacional el cual se había convertido en sitio necesario y venerable del ceremonial del Estado y la nación costarricenses. Se debe subrayar que no hubo parada militar, ya que los escolares habían reemplazado a los soldados en el ceremonial del Estado desde 1899.52 También el Teatro Nacional, inaugurado en 1897, convertido también en lugar obligado de despliegue de sociabilidades, sirvió de marco al evento cívico cultural con el cual culminaron los festejos..$^{53}$ Un componente nuevo de la fiesta fue un paseo o más bien manifestación que recorrió calles de la ciudad, la víspera del festejo. Aquí importa subrayar el carácter más bien cívico y cultural de todos estos rituales que denotan la presencia y el protagonismo de una sociedad civil en formación y crecimiento. El primer día del festejo, como complemento del concierto de la banda hubo la participación del recién fundado «Orfeón Obrero»; una muestra de la nueva visibilidad social y política que habían adquirido los sectores obreros y artesanales urbanos en el tránsito del siglo XIX al siglo XX en el contexto del surgimiento de una sociedad civil moderna. ${ }^{54}$

Una expresión similar de ese cambio fue el desfile con antorchas que, tras la retreta recorrió las calles de la capital para ir a saludar al cónsul salvadoreño. Esta manifestación

50. La República, 5 de noviembre de 1911, Número especial dedicado al centenario del «grito de independencia».

51. «La elección de los delegados de los obreros de Costa Rica al centenario de El Salvador», La República, 10 de octubre de 1911, p. 5 .

52. A partir de este año, la celebración del 15 de setiembre se convierte en una festividad escolar. El fenómeno es analizado en detalle en, Díaz, David, La fiesta de la independencia..., cit., capítulo V.

53. «Programa de los festejos que tendrán lugar en esta capital hoy y mañana, en celebración del Centenario del primer grito Independencia de Centro-América lanzado en San Salvador el 5 de Nobre. de 1811», La República, 4 de noviembre de 1911, p. 4.

54. «Los festejos del Centenario de El Salvador en Costa Rica», La República, 7 de noviembre de 1911, pp. $4-5,8$. 
o marcha como convendría llamarla era una expresión diferente de la parada militar y también del desfile de dignatarios, ambos con un lugar central en los festejos de 1891 y 1895. En esta manifestación figuraban personas comunes y corrientes en especial los más organizados o movilizados, es decir, los pequeños patronos de establecimientos urbanos y algunos de sus trabajadores, todos los cuales entremezclados eran llamados la «clase obrera». La manifestación popular terminó con un mitin en el cual se dirigieron a la multitud un representante «obrero», un representante de los estudiantes y el principal promotor del evento el ya indicado emprendedor de la memoria Octavio Castro Saborío. A estos discursos respondió el cónsul salvadoreño.

Al día siguiente, hubo la fiesta escolar, es decir, la ceremonia oficial al pie del Monumento Nacional en presencia de las máximas autoridades de gobierno. Luego hubo una recepción en el consulado salvadoreño que se extendió hasta el final de la tarde. En fin, en la noche fue la «velada lírico-literaria», en el Teatro Nacional que incluyó música, bel canto, poesía y oratoria. También hubo una escenificación plástica con modelos en vivo, alegoría de las repúblicas centroamericanas, diseñada por uno de los grandes maestros de la pintura local. Es interesante señalar la forma en la cual este artista mostró a Centroamérica, según lo que nos dice la reseña ditirámbica de este evento. La alegoría del Istmo fue encarnada por una joven de la clase alta josefina quien representaba a una indígena, «el alma de la raza» que inició, supuestamente, el camino hacia su independencia, en 1811. El símbolo es sorprendente en una Centroamérica que tenía invisibilizados a los indígenas de carne y hueso y en una Costa Rica que era, según la imagen promocionada adentro y afuera, un país esencialmente europeo. La razón del festejo no dejaba otra opción, aunque siempre permanecía latente reafirmar la descendencia de los bravíos ibéricos, como sería el caso pocos años después en las fiestas del «día de la raza». ${ }^{55}$

En los discursos oficiales no se puede inferir con facilidad cuales eran sus motivos políticos e ideológicos, salvo lo que resulta obvio, es decir, la celebración de la independencia de España y el homenaje a la amistad entre Costa Rica y El Salvador. No hay ninguna referencia directa a la situación en la cual se encuentran las repúblicas centroamericanas en su relación con su poderoso vecino que desde al menos 1907, en el marco de los tratados de Washington cumplía una función de tutela y supervisión. Precisamente, dado que esta situación de subordinación imperial era tan manifiesta, el silencio respecto de ella es muy elocuente. Así, recordar las pretendidas glorias de 1811 era una manera de enfrentar la condición subordinada de 1911. De todos modos, entre los grupos de la sociedad civil promotores del evento ya había varios voceros vectores de ideas antiimperialistas. ${ }^{56}$

También la ocasión era propicia para mostrar la urgencia de volver a unir Centroamérica en una sola república; al respecto los ardores fueron mayores en San Salvador que en San José; ya que, en Costa Rica en relación con esta delicada cuestión, gobernantes,

55. Ibidem, p. 8 .

56. En comunicación personal Héctor Lindo, historiador de El Salvador, me informa que algunos delegados de Costa Rica asumieron posturas antiimperialistas en los festejos salvadoreños. 
elites y la sociedad en su conjunto eran más bien circunspectos. Así, mientras que el presidente de El Salvador, Manuel Enrique Araujo, en un manifiesto en que convocaba a los festejos de noviembre de 1911 formulaba los deseos de ser «el último Presidente que tuviera la República de El Salvador»; el presidente de Costa Rica, Ricardo Jiménez, en respuesta a una consulta de un congreso de periodistas, reunido en San Salvador que se había pronunciado entusiastamente por la unión centroamericana, respondía que lo que consideraba conveniente era empezar por discutir «las ventajas y desventajas de la unificación propuesta». ${ }^{57}$

\section{El centenario del natalicio de Juan Rafael Mora, en 1914}

Antes de abordar este tema, conviene señalar que el 1. ${ }^{\circ}$ de mayo de 1913 se celebró la fiesta del trabajo por primera vez en Costa Rica. El evento formó parte de este ciclo de conmemoraciones y fue promovido por algunos actores de la sociedad civil que ya habían participado en el establecimiento del ceremonial nacional. En este festejo tomó carta de ciudadanía en el país la llamada cuestión social, aunque la celebración es inseparable de una indiscutible conciencia nacional asumida por los grupos de obreros y artesanos urbanos. Como ya se ha dicho, estos sectores fueron también receptores claves de la relación imperial. No en vano, la celebración asoció el $1 .^{\circ}$ de mayo como fiesta del trabajo al $1 .^{\circ}$ de mayo de 1857, día de la rendición de William Walker en la ciudad de Rivas, Nicaragua. De este modo, se pretendía establecer un lazo necesario entre la fiesta laboral, la relación con Estados Unidos y la memoria nacional, como lo hizo el escritor Joaquín García Monge en su conocido discurso del 1. ${ }^{\circ}$ de mayo de 1913. Así, con la fiesta del trabajo de 1913 se establece un puente natural con las conmemoraciones del natalicio de Juan Rafael Mora. $^{58}$

Los festejos del nacimiento de Mora fueron la actividad conmemorativa más importante del periodo en estudio, a excepción de las conmemoraciones del centenario de la independencia en 1921. Su contexto internacional inmediato fueron las movilizaciones centroamericanas, en El Salvador, Honduras y Costa Rica, contra la aprobación del tratado Chamorro-Bryan mediante el cual Estados Unidos obtenía el derecho exclusivo de construir un canal por Nicaragua; forma de evitar que alguna otra potencia lo hiciese y viniese a competir con el flamante canal de Panamá. Los gobiernos de estos tres países argüían que los términos del tratado afectaban sus derechos territoriales, pese a lo cual no habían sido consultados por ambos signatarios. A nivel interno, 1914 fue el año que en que inició una borrascosa coyuntura política en Costa Rica, enmarcada por una con-

57. «El congreso de periodistas y la unión centroamericana. Contestación del Sr. Presidente de la República», La República, 31 de octubre, p. 5.

58. Torres, Mario y Juan José Marín (ed.), Musa obrera: historia, balances y desafíos de la clase trabajadora en el centenario del 1 de mayo en Costa Rica, 1913-2013, San José, CIHAC-UCR, 2015 y De la Cruz, Vladimir, Los mártires de Chicago y el primero de mayo de 1913, San José, Editorial Costa Rica, 1984. 
tracción económica efecto de la Primera Guerra Mundial y una severa crisis fiscal, que llevó al establecimiento de una dictadura militar, en 1917, y que culminó con su caída, en 1919.

La coyuntura conmemorativa se inició con una polémica porque en la prensa hubo severas críticas al gobierno del presidente Jiménez por no haber organizado la celebración en la fecha correspondiente, es decir, el 8 de febrero, día del nacimiento de Mora. ${ }^{59}$ Tras la andanada de censuras, el Ejecutivo determinó que la celebración se realizase el 15 de setiembre siguiente, día de la independencia centroamericana, como había sido el caso de los festejos de 1891 y 1895 . Además, solicitó al Ateneo de Costa Rica organizara los actos. También convino en que otras iniciativas que habían surgido en el mismo sentido se sumaran a este grupo oficialmente encargado del evento. ${ }^{60}$ Aunque el Congreso había asignado fondos para la celebración, posteriormente el Ejecutivo se los retiró, a causa de la penuria económica. ${ }^{61}$

En esta ocasión se hizo aún más evidente el protagonismo de la sociedad civil, manifiesto ya en que uno de sus organismos fuese asignado por el gobierno para asumir la dirección de la conmemoración. Dentro de este grupo cumplió un papel destacado Octavio Castro Saborío, el emprendedor de la memoria de los festejos de 1911 como hemos visto. ${ }^{62}$ La prensa también jugó un papel muy relevante. Por ejemplo, el diario La República organizó una exitosa colecta de fondos para financiar una lápida a colocarse al frente del sitio donde nació Mora. Contribuyeron a la colecta distintas personas e instituciones, por, ejemplo las estudiantes del Colegio Superior de Señoritas. Además, este mismo diario publicó un homenaje a Mora en su edición del día 8 de febrero. En este sentido, las conmemoraciones tuvieron dos momentos, uno en setiembre con los festejos oficiales y otro previo en febrero, más espontáneo y desde sectores de la sociedad civil, en los días del natalicio de Mora. Así, por ejemplo, la Sociedad Federal de Trabajadores rindió homenaje al prócer en una velada con una conferencia complementada por un baile. ${ }^{63}$

Hubo diversas actividades en el marco de la conmemoración tales como unos juegos florales organizados por «la juventud», la publicación de un libro conmemorativo de los festejos y de una recopilación de documentos históricos relativos a la guerra contra los filibusteros; una escuela de la capital fue bautizada con el nombre de Mora, hubo un concurso para dotar de música un himno para Mora y hubo distintos homenajes fuera de San José. Los festejos se desarrollaron en cuatro actos: en la noche del 14 de setiembre

59. «El Centenario de don Juan Rafael Mora. ¡¡Hosanna al ilustre padre de la patria!!», La República, 8 de febrero de 1914, p. 1 y «El Centenario y el Gobierno», La República, 27 de febrero de 1914, p. 1. Estos editoriales censuran al gobierno por no celebrar los festejos cuando estiman correspondía.

60. «Las fiestas del Centenario de Mora», La República, 3 de marzo de 1914, p. 1. Aquí se transcribe el decreto ejecutivo respectivo publicado en La Gaceta.

61. «El Centenario de Mora», La República, 26 de agosto de 1914, p. 3. Así se informa en esta gacetilla.

62. Es interesante señalar que una de las asociaciones que participó en los festejos del centenario de Mora fue la denominada Centro 5 de Noviembre con sede en San Pedro del Mojón, una población cercana a la ciudad de San José. «El Centenario de Mora en el Centro '5 de Noviembre'», La República, 10 de febrero de 1914, p. 1.

63. «Fiesta en la Sociedad Federal de Trabajadores», La República, 24 de febrero de 1914, p. 1. 
hubo la tradicional retreta con la banda militar; el 15 en la mañana se inició con dianas y salvas de artillería, tras lo cual se realizó una ceremonia en la que se develó una placa al frente de donde nació Mora; aquí tuvieron su respectiva participación los escolares; el tercer acto fue una «gran procesión cívica» que de este lugar se dirigió al Cementerio General para inaugurar un busto de bronce del homenajeado, colocado en un recién erigido mausoleo donde se habían depositado sus restos; el busto fue bendecido por el obispo de San José. En esta ocasión hubo tres discursos de personas designadas por los organizadores del evento. En la «procesión» desfilaron los biznietos de Mora, veteranos de la guerra contra los filibusteros, autoridades civiles y militares, el cuerpo diplomático y representantes de la prensa. Cabe destacar la participación en esta marcha de distintas agrupaciones de la sociedad civil, el aspecto más novedoso en relación con las celebraciones previamente descritas. Según el cronista de estos eventos la concurrencia fue de 10.000 personas, cifra quizás abultada. En asocio con estos eventos, hubo dos «matchs» de «foot-ball», un nuevo componente en este tipo de festejos. El último acto de los festejos del natalicio de Mora fue una velada cívica y cultural en el Teatro Nacional la noche del día 15.

Con la conmemoración del centenario del nacimiento de Juan Rafael Mora culmina su proceso de fabricación como héroe nacional tanto del Estado como de la nación costarricenses. Este culto muestra ya claramente dos formas opuestas de enaltecer su lucha que son dos maneras, una implícita y la otra explícita de tomar posición frente a la llegada de la relación imperial: por un lado, están quienes desde las esferas oficiales con prudencia se mantienen en los parámetros del nacionalismo gubernamental y cuidadosamente disocian al gobierno de Estados Unidos de la empresa filibustera de William Walker. Por ejemplo, Leonidas Pacheco, Ministro de Relaciones Exteriores de Costa Rica, en el discurso pronunciado en la velada realizada en el Teatro Nacional, el 15 de setiembre de 1914, afirmó en forma categórica que Walker «ultrajaba con sus torpes manos, el pabellón de las barras y las estrellas, el pabellón que es emblema de un gran país, en donde Costa Rica siempre encontró respetado su derecho y amparada su justicia». ${ }^{64}$ Similar circunspección se observa en las palabras pronunciadas en los desfiles de ese mismo día, ya que se denunció «la tiranía y la invasión bucaneras», pero nadie del sector oficial nombró el país del cual procedían esos despreciables invasores. Además, sintomáticamente, se guardó silencio sobre la circunstancia de que Nicaragua estaba ocupada militarmente por Estados Unidos en aquel momento.

Por otro lado, están aquellos que desde la sociedad civil adoptan un discurso más claramente antiimperialista. Por ejemplo, Augusto C. Coello, político, periodista y escritor hondureño, exdirector de La República, residente en ese momento en Costa Rica, critica tanto el entreguismo de las elites centroamericanas como el imperialismo estadounidense. Coello enfatiza las divisiones de las elites de Nicaragua que han facilitado tanto

64. Castro, Octavio (ed.), El Centenario del Benemérito de la Patria Ex-presidente de la República General don Juan Rafael Mora 1814-1914, San José, Tipografía Nacional, 1915, p. 87. 
la llegada de Walker como la ocupación de los marines en el presente. ${ }^{65}$ Una posición similar se encuentra en el discurso pronunciado por Camilo Cruz Santos, escritor y dramaturgo costarricense, en la ceremonia realizada en el cementerio. «Presagios siniestros —advierte- estremecen los amplios horizontes de la América Hispana; ya perfilan sobre las crestas de los montes sus ávidas siluetas las águilas del Norte.» Y pesimista agrega: «iYa no verán nuestros jocundos campos la lucha abierta en épico palenque; ique esta generación sin fe, ni ideal, ni gloria, desdeña los patricios homenajes, y recibe a los Bárbaros con flores! ${ }^{66}$ Con menos lirismo Gerardo Vega, representante de la Sociedad Federal de Trabajadores, denuncia a «los bucaneros, cuya águila se percibe en el horizonte en actitud amenazante». ${ }^{67}$

Los festejos del natalicio de Mora tuvieron eco en los otros países centroamericanos, como había sido el caso de celebraciones previas y, en este sentido, estas fiestas no pueden ser plenamente entendidas si no se incluye en ellas su dimensión regional, no sólo porque lo que se conmemora así lo exige, ya que la independencia fue centroamericana y la guerra contra los filibusteros también, sino por la coordinación e interdependencia de los propios festejos. El presente y el pasado de los países centroamericanos forman parte de una historia conectada a doble nivel en el espacio ístmico y latinoamericano y en el espacio hemisférico por la vinculación con Estados Unidos. En suma, a inicios de la Primera Guerra Mundial las fiestas del Estado y la nación costarricenses no podrán realizarse sin tomar nota de la existencia de una sociedad civil muy activa y sin evitar confrontaciones en relación con la presencia imperial de Estados Unidos en la región centroamericana. Además, en el ceremonial habían ganado protagonismo los escolares en detrimento de los militares y los festejos eran de carácter predominantemente laico.

\section{El 11 de abril como fiesta oficial, 1915 (1916)}

En la coyuntura conmemorativa del tercer lustro del siglo XX marcada por la agitación provocada por la suscripción del tratado canalero Chamorro-Bryan entre Estados Unidos y Nicaragua se inscribe la declaratoria oficial del 11 de abril como «feriado y fiesta nacional», en junio de $1915 .{ }^{68}$ En consonancia con el decreto legislativo se realizó la primera gran conmemoración de la fecha en forma oficial el 11 de abril de 1916, sexagésimo aniversario de la batalla de Rivas. De este modo, el culto a Mora quedará complementado con el de Santamaría y viceversa. En ambos casos se trata de un uso de la memoria para hacer la recepción de la relación imperial, en versiones nacionales moderadas o en versio-

65. Ibidem, p. 64.

66. Ibidem, p. 108.

67. Ibidem, p. 111.

68. «Poder Legislativo. n. ${ }^{\circ}$ 26. 18 de junio de 1915», República de Costa Rica-América Central, Colección de Leyes y Decretos. Primer Semestre 1915, Edición Oficial, Tipografía Nacional, 1915, pp. 514-515. Sobre el proceso de construcción de Juan Santamaría como héroe, véase: Méndez, Rafael Ángel, Imágenes del poder. Juan Santamaría y el ascenso de la nación costarricense (1860-1915), San José, EUNED, 2007. 
nes antiimperialistas más estridentes. En la producción de ambas versiones son protagónicos individuos y grupos de la sociedad civil. En este sentido, conviene señalar que el festejo oficial de 1916 estuvo precedido por una celebración no oficial en 1915 en la que se hicieron presentes en la ciudad de Alajuela grupos y personas que habían participado en los actos del natalicio de Mora. ${ }^{69}$ El formato de ambas celebraciones fue similar al ya establecido desde principios del siglo XX para los actos de conmemoración de la independencia y también se inspiró en los actos del centenario de Mora del año anterior. La celebración de 1916 como primer festejo oficial tuvo grandes proporciones con la presencia de las más altas autoridades del gobierno. Aquí, como en 1914, los discursos oficiales se mantuvieron dentro de los parámetros del nacionalismo gubernamental, aunque se debe decir que el presidente Alfredo González no ocultaba sus ideas críticas frente al capital extranjero y a las políticas estadounidenses. ${ }^{70}$

\section{Los festejos del «día de la raza», en 1915}

Como ya se dijo, desde 1892 el 12 de octubre había sido decretado fiesta oficial por parte del gobierno de Costa Rica y desde entonces en la prensa se había recordado en forma irregular la efeméride, pero en los años 1910 la conmemoración fue adquiriendo relieve, en el contexto de la difusión de la propaganda desde España en favor del fortalecimiento de los lazos entre la «madre patria» y las «jóvenes repúblicas». ${ }^{71}$ Así, por ejemplo, el 12 de octubre de 1911, La República consagró un número especial al Almirante, el cual en la segunda página incluía las fotografías de «Don Gaspar Ortuño y Don Adrián Collado. Dos de los miembros más importantes de la Colonia Española en Costa Rica». Seguían a continuación una serie de artículos escritos por destacados intelectuales costarricenses sobre diversos aspectos de la figura de Colón y dos relativos a la historia de Costa Rica, del periodo colonial y del siglo XIX.72

De este modo, el 12 de octubre de 1915 se celebró en forma oficial la «Fiesta de la Raza» con el respaldo formal de la representación española en Costa Rica, con el apoyo de las asociaciones de la colonia española en el país, de las representaciones de otros países latinoamericanos y en asocio con el Ateneo de Costa Rica y la prensa nacional. En esta ocasión los círculos de obreros y artesanos no fueron integrados a la organización de los

69. «Las fiestas del 11 de abril en Alajuela», La República, 14 de abril de 1915, p. 2. Entre los oradores del evento no podía faltar el emprendedor de la memoria Octavio Castro Saborío.

70. La prensa informó ampliamente sobre este festejo: «Fiestas del 11 de abril de 1916 en la ciudad de Alajuela. Programa», La Información, 11 de abril de 1916, p. 6; «Las fiestas patrióticas celebradas ayer en la ciudad de Alajuela», La Información, 12 de abril de 1916, p. 4. Este número y los de dos días siguientes contienen más información sobre la celebración. También véase, Díaz, David, Historia del 11 de abril. Juan Santamaría entre el pasado y el presente (1915-2006), San José, EUCR, 2006, pp. 7-12.

71. La República, 18 de agosto de 1915, p. 2, «Fiesta de la raza Ibero Americana». Aquí se transcribe una circular de la Unión Iberoamericana invitando a organizar el festejo.

72. Número especial dedicado a Colón y al «descubrimiento de América», La República, 12 de octubre de 1911. 
actos, la cual quedó en manos de integrantes de las elites costarricenses. La prensa enfatizó que esta era la primera vez que se realizaba esta conmemoración en Costa Rica y pronosticó su brillo y magnitud..$^{73}$

Hubo desfiles, ceremonias escolares, la colocación de la primera piedra de un monumento a Colón, el bautizo de una sección de la avenida central de la capital con el nombre de Paseo Colón, un lucido baile que reunió a la crema y nata de la clase alta local en el Teatro Nacional, bailes de los círculos de obreros y de los miembros del magisterio, partidos de fútbol, etc. No hubo parada militar. En el desfile principal se distinguieron los boys-scouts, una asociación que acaba de surgir en Costa Rica. También desfiló una carroza en la que iban representadas los dos componentes de la raza iberoamericana y España y Costa Rica, por medio de cuatro bellas jóvenes. En la elaboración de esta carroza participó un arquitecto de origen catalán y el infaltable Octavio Castro Saborío. Según el cronista del evento: «Fue un gran éxito artístico este detalle de las fiestas, pues en realidad el símbolo de la carroza es el que hay en todos los corazones: la unión de la vieja España con la joven y agradecida América.» A diferencia de otros festejos en esta ocasión hubo una actividad religiosa, una misa de campaña oficiada por el obispo a la que asistió el clero, seminaristas e integrantes de las órdenes religiosas, junto con autoridades civiles. Este fue un momento de apoteosis en el cual tanto el gobierno, como la sociedad en su conjunto hicieron alarde de los orígenes hispánicos de Costa Rica y se promovió un sentimiento de orgullo de pertenecer a la «raza hispanoamericana». No por azar, iban en el desfile los retratos de Colón y de Juan Vázquez de Coronado, el conquistador de Costa Rica.

Los actos principales consistieron en una retreta la víspera del 12, un desfile, la puesta de la primera piedra de un monumento a Colón, una actividad lírico-musical con discursos en el Centro Español y un baile de gala en el Teatro Nacional. Hubo también celebraciones en el Centre Catalá con presencia del personal docente e integrantes de la colonia española y en la Sociedad Federal de Trabajadores. También hubo celebraciones fuera de la ciudad capital en ambos puertos y en la ciudad de Heredia. Como se ve los festejos fueron muy animados. Aunque hubo participación de las autoridades de gobierno, esta fiesta fue una iniciativa lanzada por la representación española y secundada por miembros de las elites políticas e intelectuales locales, representadas por el Ateneo.

En términos de los cambios en el ceremonial se debe señalar, como en 1911, la presencia de un partido de fútbol en el cual se disputó un trofeo donado por la colonia española. La inclusión de ese evento en los festejos fue objeto de debate entre los miembros

73. Véase: «Colón, el Hombre de ayer. América, el continente de hoy. Nuestra raza, la Raza del Porvenir», La Información, 12 de octubre de 1915, p. 1; «La Fiesta de la Raza. El programa oficial», La Información, 12 de octubre de 1915 , p. 4. «El éxito más completo y brillante ha coronado la celebración de la Fiesta de la Raza. El tiempo espléndido, el entusiasmo del público y el acierto y empeño de la Comisión Organizadora, contribuyeron al éxito. Colocación de la primera piedra del Monumento a Colón. La procesión cívica. Match de foot-ball. Misa de Campaña. Velada literaria», La Información, 13 de octubre de 1915, p. 4-6. «La fiesta de la raza a vuelo de pájaro», La República, 14 de octubre de 1915, p. 1. El tono de esta crónica, menos detallada, es un poco irónico. 
del comité organizador, ya que hubo alguien que opinó que le restaba solemnidad y seriedad al festejo. También es interesante señalar que en la fiesta de los docentes se programó una actividad con «cinematógrafo». Los festejos fuera de la capital fueron organizados por los círculos de artesanos.

Ricardo Fernández Guardia, escritor e historiador, el más importante de la primera mitad del siglo XX, presidente de la comisión organizadora de los festejos y presidente del Ateneo pronunció un discurso en el cual resumió las ideas básicas que presidieron la celebración. Así, en su opinión:

Si hay una raza homogénea sobre la tierra, esa es sin disputa la raza iberoamericana. Ninguna conserva con igual tenacidad, a través del tiempo y de los azares de la existencia, sus caracteres fundamentales. Ni la mezcla de sangre extraña, ni las condiciones climatológicas, ni las diferencias del régimen político han podido alterar sustancialmente su índole. En todos los pueblos que tienen por cuna el viejo solar ibero, se notan las mismas virtudes y los mismos defectos, apenas modificados o atenuados por las circunstancias especiales de su vida. ${ }^{74}$

De esta manera, la Fiesta de la Raza pretendía «mantener vivo el recuerdo de su grandeza pasada, estimular el anhelo de la futura grandeza y consolidar lazos de solidaridad que a todos los pueblos iberoamericanos unen por encima de las fronteras y los mares.» Esta raza, «no tiene nada que envidiar a ninguna, así sea la más ilustre o la más soberbia.» Queda claro que va hay una comparación implícita entre esta raza y la «raza anglosajona». Después de esta apología de la raza iberoamericana el distinguido historiador procede a ensalzar a la «raza latina», en su conjunto. «A esta noble raza latina, que con el pueblo griego edificó la antigua civilización europea, se debe el renacimiento de las artes y de las letras anquilosadas por la furia de los bárbaros; a ella se deben el descubrimiento de América y la proclamación de los derechos del hombre.» $\gg^{75}$ Por oposición a quienes omiten cualquier alusión a Estados Unidos y despliegan un nacionalismo inocuo, el distinguido historiador se expresa mediante un antiimperialismo elíptico, propio de ciertos políticos e intelectuales liberales, reacios a las ideas radicales que han penetrado en los círculos de obreros y artesanos y entre algunos intelectuales influidos por el anarquismo.

Como se ve en los festejos se rindió homenaje por separado a la «raza iberoamericana» y a la «raza latina». A la primera se le atribuyó un gran porvenir y la condición de ser esperanza para la humanidad por la paz en que vivía, mientras Europa había descendido a la peor barbarie desde 1914. Esta idea expresada en un editorial de La Información estaba siendo propagandizada por la Unión Iberoamericana y por sectores oficiales españoles. ${ }^{76}$ Por su parte, el diario La República se mostró elogioso en relación con la raza ibérica, pero no así con la americana, compuesta de «palúdicos morales», que cargaba taras

74. «El éxito más completo y brillante ha coronado la celebración de la Fiesta de la Raza», La Información, 13 de octubre de 1915.

75. Ibidem.

76. «Colón, el Hombre de ayer. América, el continente de hoy. Nuestra raza, la Raza del Porvenir», La Información, 12 de octubre de 1915, p. 1 
antiguas. La crítica a la raza americana era ejemplificada por la confusa situación política imperante en el país. ${ }^{77}$ Aquí, como en otras ocasiones, se asoma el pesimismo histórico en relación con los pueblos hispanoamericanos, aunque el comentario no puede ser disociado de la coyuntura política costarricense y de la circunstancia de que procede de un medio de oposición al gobierno. De todos modos, la raza que en ese día se exaltaba a pesar de sus glorias y promesas se encontraba a la defensiva frente al empuje de la raza anglosajona. El tema del conflicto entre ambas razas se había convertido en leit motiv de la opinión publica en Costa Rica desde al menos 1898. Como bien señala Marcilhacy, el festejo del «día de la raza» expresa una confrontación entre un panamericanismo impuesto y una herencia hispánica idealizada. ${ }^{78}$

\section{Las fiestas del centenario de la independencia de Centroamérica, en 1921}

Los festejos del centenario de la independencia fueron celebrados en un momento en que Costa Rica había dejado atrás la edad de la inocencia. En efecto, en el cuatrienio 19171921, el país había pasado por una dictadura militar, había padecido la intransigencia imperial del presidente Woodrow Wilson, había estado al borde de una intervención militar estadounidense y había pasado por una corta y poco gloriosa guerra con Panamá por cuestiones limítrofes. ${ }^{79}$ Los blasones de la «Suiza centroamericana» habían quedado muy maltratados, pero, de todos modos, tras la caída de la dictadura regresó a una apariencia de normalidad y a darle nueva vida a su discurso de nación excepcional en el contexto regional.

Además, el contexto inmediato del centenario fue el intento de los cinco países del Istmo por resucitar la República Federal Centroamericana. Así, entre diciembre de 1920 y enero de 1921, representantes de estos países se reunieron en San José y acordaron un pacto de unión. El acuerdo fue empañado por el conflicto fronterizo entre Panamá y Costa Rica en los meses de febrero y marzo de 1921. Aunque Panamá venció a Costa Rica, Estados Unidos impuso un arreglo que los panameños consideraron lesivo a sus intereses y por esa razón decidieron no sumarse a los festejos del centenario. Tampoco ayudó a las perspectivas del intento de reunificación del Istmo la circunstancia de que la delegación nicaragüense no suscribiese el pacto. La pretensión de revivir la federación centroamericana provocó mucha polémica en Costa Rica, un país que tenía una larga trayectoria de reticencia frente a cualquier intento unionista. Al final, el gobierno costarricense desistió de participar en el intento unionista, de modo que siguieron adelante con él, Guatemala, El Salvador y Honduras.

Los festejos oficiales a nivel centroamericano se celebraron en la ciudad de Guatema-

77. «Crónica ligera. Los prestigios de nuestra raza», La República, 15 de octubre de 1915, p. 1.

78. Marcilhacy, David, Raza hispana..., cit., pp. 334 ss.

79. Murillo, Hugo, Tinoco y los Estados Unidos. Génesis y caída de un régimen, San José, EUNED, 1981. Este es el mejor estudio que existe hasta hoy sobre esta coyuntura crítica de la historia de Costa Rica. 
la, según fue acordado en la citada reunión de San José, con delegados del más alto nivel de los otros estados. Además, cada república, por su cuenta, organizó sus fiestas. Hubo un contraste entre las celebraciones en los países del Triángulo Norte, los que habían mantenido el proyecto de reconstrucción federal y los del sur del Istmo. En el caso de los primeros, los festejos tuvieron mayor brillo, su tema central fue el unionismo y se centraron en la participación popular y en actividades de entretenimiento, con menor énfasis en escolares y colegiales. En el caso de Nicaragua los festejos fueron opacados por la intervención estadounidense y porque el gobierno enfrentaba una rebelión. Una particularidad de Guatemala fue la exclusión de la Iglesia Católica de la celebración. ${ }^{80}$

En Costa Rica, los festejos presentaron continuidades, ya que el eje de la conmemoración fueron las fiestas escolares y novedades porque la iglesia católica participó en los eventos oficiales y con ella las ceremonias religiosas. A propósito de la participación de la iglesia y de la presencia del ceremonial religioso, se inauguró un busto de la reina Isabel La Católica. Otra novedad en las ceremonias fue que el acto principal no se verificó al pie del Monumento Nacional, sino en la plazoleta al frente del Teatro Nacional, en donde se inauguró una estatua del primer jefe de Estado, Juan Mora Fernández. Hubo festejos cívicos y culturales en todo el territorio nacional y como en otros eventos similares, los círculos obrero-artesanales participaron con actos cívico-culturales y bailes. La fiesta tuvo como evento social máximo un baile de gala en el Teatro Nacional el día 15, remedado por los «obreros», en otro baile en el mismo lugar el día $17 .{ }^{81}$

Tras la separación de Costa Rica del intento unionista en los meses previos al 15 de setiembre, en términos ideológicos la fiesta se concentró en la celebración de la nación costarricense y conscientemente se evitó toda exaltación del unionismo. No obstante, debe señalarse que el pequeño círculo de unionistas locales organizó un festejo en un hotel de la capital..$^{82}$ El énfasis en la fiesta escolar y el homenaje a Juan Mora Fernández fueron un medio para exaltar las peculiaridades de la nación costarricense y para poner en escena un mito que ya tenía mucha difusión en el país, formulado mediante la frase estereotipada de «más maestros que soldados». El esfuerzo era necesario en el contexto de la historia reciente del país en el cual la excepcionalidad había quedado en el suelo.

A pesar de la gran cantidad de información que circuló en la prensa en setiembre de 1921 y a pesar de la publicación de un voluminoso número especial del Diario de Costa Rica el día 15 de setiembre, es poco lo que se puede inferir sobre las cuestiones políticas e ideológicas subyacentes a la conmemoración. Así, el editorial de este número especial volvió a recordar el excepcionalismo costarricense, aunque lamentó la caótica situación económica y fiscal del país y urgió al gobierno a formular una «política económica». ${ }^{83}$ En

80. Fumero, Patricia, National Identities in Central America in a Comparative Perspective: The Modern Public Sphere and the Celebration of Centennial of Central American Independence September 15, 1921, Ph. D. Thesis, Kansas University, 2005. Esta tesis estudia la celebración en todos los países del Istmo.

81. El programa oficial de los festejos aparece en «El primer Centenario de la Independencia», Diario de Costa Rica, 10 de setiembre de 1921, p. 3.

82. Díaz, David, La fiesta de la independencia ..., cit., pp. 216-218.

83. «El Centenario», Diario de Costa Rica, 15 de setiembre de 1921, p. 53. 
este sentido, dada la ausencia en la prensa de este tipo de textos, llama la atención un artículo que, tras recordar las conocidas virtudes raciales y políticas de Costa Rica, invoca al panamericanismo y a la doctrina Monroe como recursos para garantizar su soberanía e independencia como nación pequeña frente al poder de un gran vecino, que no se nombra, cuyos apetitos se espera conjurar por medio de la solidaridad continental. ${ }^{84}$ Este recurso de pretender domar al monstruo por medio del derecho internacional formaba parte de los repertorios de recepción de la relación imperial ya elaborados por los gobiernos y las elites centroamericanas desde los primeros años del siglo XX.

\section{Conclusiones}

Entre los argumentos de quienes estaban a favor del restablecimiento de la unión centroamericana, en 1921, estaba la tesis de que este podía ser el mejor recurso para hacerle frente al dominio de Estados Unidos. Durante las tres décadas que hemos considerado en este ensayo, las fiestas estatales y nacionales realizadas en Costa Rica fungieron como una manera de hacer la recepción de la relación imperial impuesta. Las conmemoraciones, en forma indirecta más usualmente que directa, eran una forma de posicionarse de tal condición desde un lugar de debilidad y de subordinación. La fiesta era un espacio en el cual se podía travestir, escenificar, y también nombrar la asimetría. En las esferas oficiales, la vía escogida era elíptica o más bien un silencio que por su mutismo delataba; en otros círculos, de intelectuales, escritores, periodistas críticos y dirigentes obreros, la palabra era pronunciada o gráficamente representada mediante la caricatura. ${ }^{85}$ Algunas veces podía ser una pieza de oratoria, otras una novela y, con regularidad, un verso encendido, pero usualmente desabrido.

A lo largo de estas tres décadas las fiestas experimentaron modificaciones: en primer lugar, un proceso de secularización creciente, en el sentido de que la Iglesia católica perdió protagonismo en su ceremonial; en segundo lugar, el ritual militar terminó siendo subordinado por el ceremonial civil y, en especial, adquirió centralidad la fiesta escolar; en tercer lugar, el Estado compartió la producción de este tipo de eventos con sectores de la sociedad civil, en particular, los círculos de obreros y artesanos y aquí conviene singularizar el papel desempeñado por los llamados emprendedores de la memoria; por último, el componente de entretenimiento de los festejos al final fue marcado por las nuevas expresiones de la cultura de masas como el fútbol y las vistas cinematográficas y por el deseo tanto entre las elites como en los grupos subalternos de apropiarse de las formas de la llamada alta cultura, como la música y la lírica.

84. Guerrero, José, «Reflexiones con motivo del Centenario de Nuestra Independencia Política», La Tribuna, 15 de setiembre de 1921, pp. 19 y 21.

85. Vindas, Sofía «Cerdos que se alimentan con oro: el imperialismo yankee en las caricaturas costarricenses, 1900-1930», Ístmica. Revista de la Facultad de Filosofía y Letras (UNACR), 21, 2018, pp. 95-148. <https:// doi.org/10.15359/istmica.21.8>. 
Para terminar, aunque el punto de mira ha sido Costa Rica, ha quedado manifiesto en este ensayo que la fiesta era un fenómeno conectado y transnacional; ya porque remetía a una historia común de los países centroamericanos, en un caso, o hispanoamericanos, en otro; ya fuese por la intención de crear un sentimiento de pertenencia compartido más allá de las fronteras. También la fiesta remitía necesariamente a los entrecruces de las historias de los países centroamericanos con la de Estados Unidos. Pero las historias conectadas no solo eran hemisféricas, sino que trascendían a las relaciones con la llamada «madre patria».

En fin, si en este ensayo hemos querido mostrar que la fiesta se inscribía en el repertorio de formas de recepción de la relación imperial y se articulaba de forma funcional y también contradictoria con el repertorio de formas de imposición de la relación imperial, su encargo era, para recordar de nuevo al amigo y colega Garavaglia, «construir el Estado, inventar la nación», en el caso en estudio una nación excepcional, una verdadera «Suiza» del «mundo de Colón».

\section{Fuentes}

Prensa: (disponible en el sitio <http://sinabi.go.cr/ver//biblioteca digital/periodicos/>)

Diario de Costa Rica, 1921.

El Heraldo, 1891.

La Gaceta. Diario Oficial, 1891-1921.

La Información, 1915-1916.

La Prensa Libre, 1891-1892.

La República, 1891-1916.

La Tribuna, 1921.

Costa Rica Ilustrada. Revista de Ciencias, Artes y Literatura, 1891.

\section{Fuentes Impresas:}

Castro, Octavio (ed.), El Centenario del Benemérito de la Patria Ex-presidente de la República General don Juan Rafael Mora 1814-1914, San José: Tipografía Nacional, 1915.

Las fiestas del 15 de septiembre de 1895. Celebradas con motivo de la inauguración del Monumento Nacional erigido en San José a los héroes del 56 y 57, (Edición ordenada por el Gobierno de la República), San José, Tipografía Nacional, 1897.

República de Costa Rica-América Central, Colección de Leyes y Decretos. Primer Semestre 1915, Edición Oficial, Tipografía Nacional, 1915.

\section{Bibliografía}

Acuña, Víctor H., «Costa Rica: la fabricación de Juan Rafael Mora (siglos XIX-XXI)», Diálogos. Revista de Historia (UCR), n. ${ }^{\circ} 16,2015$, pp. 39-76. 
Coatsworth, John H., Central America and the United States. The Clients and the Colossus, New York, Twayne Publishers, 1994.

De la Cruz, Vladimir, Los mártires de Chicago y el primero de mayo de 1913, San José, Editorial Costa Rica, 1984.

Díaz, David, «Fiesta e imaginería cívica: la memoria de la estatuaria de las celebraciones patrias costarricenses, 1876-1921». Revista de Historia (UNA-UCR), 49-50, 2004, pp. 111-154.

-, Historia del 11 de abril. Juan Santamaría entre el pasado y el presente (1915-2006), San José, EUCR, 2006.

—, La fiesta de la independencia en Costa Rica, 1821-1921, San José, EUCR, 2007.

Fumero, Patricia, El Monumento Nacional. Fiesta y develización, setiembre de 1895, Alajuela: Museo Histórico Cultural Juan Santamaría, 1998.

—, «La celebración del santo de la patria: la develización de la estatua del héroe nacional costarricense, Juan Santamaría, el 15 de setiembre de 1891», en Enríquez, Francisco e Iván Molina (ed.), Fin de siglo XIX e identidad nacional en México y Centroamérica, Alajuela, Museo Histórico Cultural Juan Santamaría, 2000, pp. 403-435.

- National Identities in Central America in a Comparative Perspective: The Modern Public Sphere and the Celebration of Centennial of Central American Independence September 15, 1921, Ph. D. Thesis, Kansas University, 2005.

Garavaglia, Juan Carlos, Construir el estado, inventar la nación. El río de la Plata, siglos XVIII-XIX, Buenos Aires, Prometeo Libros, 2007.

Jelin, Elizabeth, Los trabajos de la memoria, Madrid y Buenos Aires, Siglo XXI Editores, 2002.

Lacaze, Catherine, Francisco Morazán. Le Bolivar de l'Amérique Centrale, Rennes, Presses Universitaires de Rennes, 2018.

Marcilhacy, David, Raza hispana. Hispanoamericanismo e imaginario nacional en la España de la Restauración, Madrid, Centro de Estudios Políticos y Constitucionales, 2010.

Méndez, Rafael Ángel, Imágenes del poder. Juan Santamaría y el ascenso de la nación costarricense (1860-1915), San José, EUNED, 2007.

Murillo, Hugo, Tinoco y los Estados Unidos. Génesis y caída de un régimen, San José, EUNED, 1981.

Rodríguez, Miguel, Celebración de «la raza»: una bistoria comparativa del 12 de octubre, México, Universidad Iberoamericana, 2004.

Torres, Mario y Juan José Marín (ed.), Musa obrera: historia, balances y desafíos de la clase trabajadora en el centenario del 1 de mayo en Costa Rica, 1913-2013, San José, CIHAC-UCR, 2015.

Vindas, Sofía «Cerdos que se alimentan con oro: el imperialismo yankee en las caricaturas costarricenses, 1900-1930», Ístmica. Revista de la Facultad de Filosofía y Letras (UNA), n. ${ }^{\circ}$ 21, 2018, pp. 95-148. <https://doi.org/10.15359/istmica.21.8>. 